\title{
Stored Carbon in the Grassland Habitat of Gorumara National Park, West Bengal, India
}

\author{
Sumita Ghatak ${ }^{1}$, Abhijit Mitra ${ }^{2}$, Prosenjit Pramanick ${ }^{3}$, Atanu Kumar Raha ${ }^{4}$ \\ Department of Forest and Environmental Science, Techno India University, Kolkata, India ${ }^{1,4}$ \\ Department of Marine Science, University of Calcutta, Kolkata, India ${ }^{2}$ \\ Department of Oceanography, Techno India University, Kolkata, India ${ }^{3}$
}

\begin{abstract}
The biomass and stored carbon in two dominant grass species (Daddha and Chepti) widely available in the Gorumara National Park was assessed during August, 2015. The average Above Ground Biomass (AGB) followed the order Daddha $\left(15.34 \mathrm{Kg} \mathrm{m}^{-2}\right)>$ Chepti $\left(11.23 \mathrm{Kg} \mathrm{m}^{-2}\right)$ in Sandy soil. In case of Sandy loam soil, the AGB followed a reverse order i.e., Chepti $\left(17.54 \mathrm{Kg} \mathrm{m}^{-2}\right)>$ Daddha $\left(16.72 \mathrm{Kg} \mathrm{m}^{-2}\right.$ ). The average Below Ground Biomass (BGB) followed the order Daddha $\left(5.05 \mathrm{Kg} \mathrm{m}^{-2}\right)>$ Chepti $\left(2.22 \mathrm{Kg} \mathrm{m}^{-2}\right)$ in sandy soil. In case of Sandy loam soil, the average BGB followed the order Daddha $\left(6.25 \mathrm{Kg} \mathrm{m}^{-2}\right)>$ Chepti $\left(3.46 \mathrm{Kg} \mathrm{m}^{-2}\right)$. The average Above Ground Carbon (AGC) followed the sequence Daddha $\left(7.18 \mathrm{Kg} \mathrm{m}^{-2}\right)>$ Chepti $\left(5.51 \mathrm{Kg} \mathrm{m}^{-2}\right)$ in Sandy soil and Chepti $\left(8.69 \mathrm{Kg} \mathrm{m}^{-2}\right)>\mathrm{Daddha}^{-2}$ $\left(8.04 \mathrm{Kg} \mathrm{m}^{-2}\right)$ in Sandy loam soil. The average Below Ground Carbon (BGC) in Daddha and Chepti were $2.23 \mathrm{Kg} \mathrm{m}^{-2}$ and $1.05 \mathrm{Kg} \mathrm{m}^{-2}$ respectively in Sandy soil. In Sandy loam soil, the values were relatively higher $2.93 \mathrm{Kg} \mathrm{m}^{-2}$ in Daddha and $1.69 \mathrm{Kg} \mathrm{m}^{-2}$ in Chepti. Considering the stored carbon in the two species, $\mathrm{CO}_{2}$ - equivalent was estimated and the results support the potential of the species in offsetting $\mathrm{CO}_{2}$ at the local level preferably that grow on sandy loam type of substratum.
\end{abstract}

Key words: Gorumara National Park (GNP), Above Ground Biomass (AGB), Below Ground Biomass (BGB), Above Ground Carbon (AGC), Below Ground Carbon (BGC), Carbon Sequestration.

\section{INTRODUCTION}

Grass species have immense role in regulating the $\mathrm{CO}_{2}$ budget in the atmosphere. However, this particular ecosystem service of the grassland have not been quantified properly all though the species along with the underlying substratum act as the major sink of $\mathrm{CO}_{2}$. It is to be noted in this context that the volume of the carbon sink in grassland is extremely dynamic and primarily depends on edaphic and natural factors. The stored carbon in the grassland habitat is regulated by the growth, decay and death of the organisms; even the grassland management practices like cut back followed by burning, overwood removal from grassland, new plantation in grassland also influence the stored carbon in the grassland system. All the floral species of grassland under producer community store carbon in organic form which are emitted back to the atmosphere after their death and decay through the process of microbial decomposition. During the entire life cycle of the grass species, sequestration of carbon occurs as a function of their growth pattern. Carbon storage data varies substantially among sites, which depicts the role of soil quality and composition in the process of carbon sequestration (Mitra et al, 2012). The fecal matters of the wild animals, especially herbivores and their decay and decomposition also add substantial amount of organic carbon in the grassland ecosystem.

The present study was undertaken in the grassland habitat of Gorumara National Park located in the Northern part of the State of West Bengal, India during August, 2015. It is the first such study in this part of the Indian Subcontinent and may serve as baseline data of biomass and stored carbon of these grass species.

\section{MATERIALS \& METHODS}

\section{Description of site}

This study was undertaken in Gorumara National Park (GNP) situated between latitude $26^{\circ} 47^{\prime} 12.5^{\prime \prime}$ North to $26^{\circ} 43$ '25.6" North and longitude 88 52 '04.2" East to $88^{0} 47^{\prime} 07.3^{\prime \prime}$ East in the Jalpaiguri District, West Bengal, India (Figure 1).

The GNP sustains rich genetic diversity of flora and fauna. A Wild Life Sanctuary (WLS) since 1949 and a National Park (NP) since 1992, within an enclosure of merely 90 $\mathrm{km}^{2}$, is harboring a rich heritage of floral and faunal diversities, unaffected over years. GNP is famous for one of the last small pockets in Eastern India harbouring natural population of Great Indian one horned Rhinoceros, along with other mega herbivores like Indian Elephant, Gaur or Indian Bison, Sambar and other herbivores hog deer, barking deer, spotted deer and members of the order Carnivora. The National Park is located in the flood plains of Jaldhaka and Murti river and other medium and small rivers and rivulets which have created a pocket of grassland. The entire tract of Gorumara National Park comes under North Indian Moist Tropical Forest as per Champion Seth's classification. However, on basis of crop composition four major forest types namely Wet Mixed Forest (Wet Semi-evergreen forest), Mixed Sal Forest, Riparian Forests (Evergreen forests) and Savannah Grassland have been identified in this system. The riverine grassland and savannah woodland occupy about $10 \%$ of total plant cover of the National Park. This type of vegetation offers best grazing ground for Great Indian One-horned Rhinoceros, the flagship species of this PA and elephants, gaurs, sambar, hog deer, spotted deer and 
other herbivores (Management Plan of Gorumara NP, which two main species are Daddha (Saccharam narenga) 2007). This National Park has some 32 types of grass and Chepti (Themeda arundinacea). A general description species (Management Plan of Gorumara NP, 2007) out of of the two species is given in Table 1.

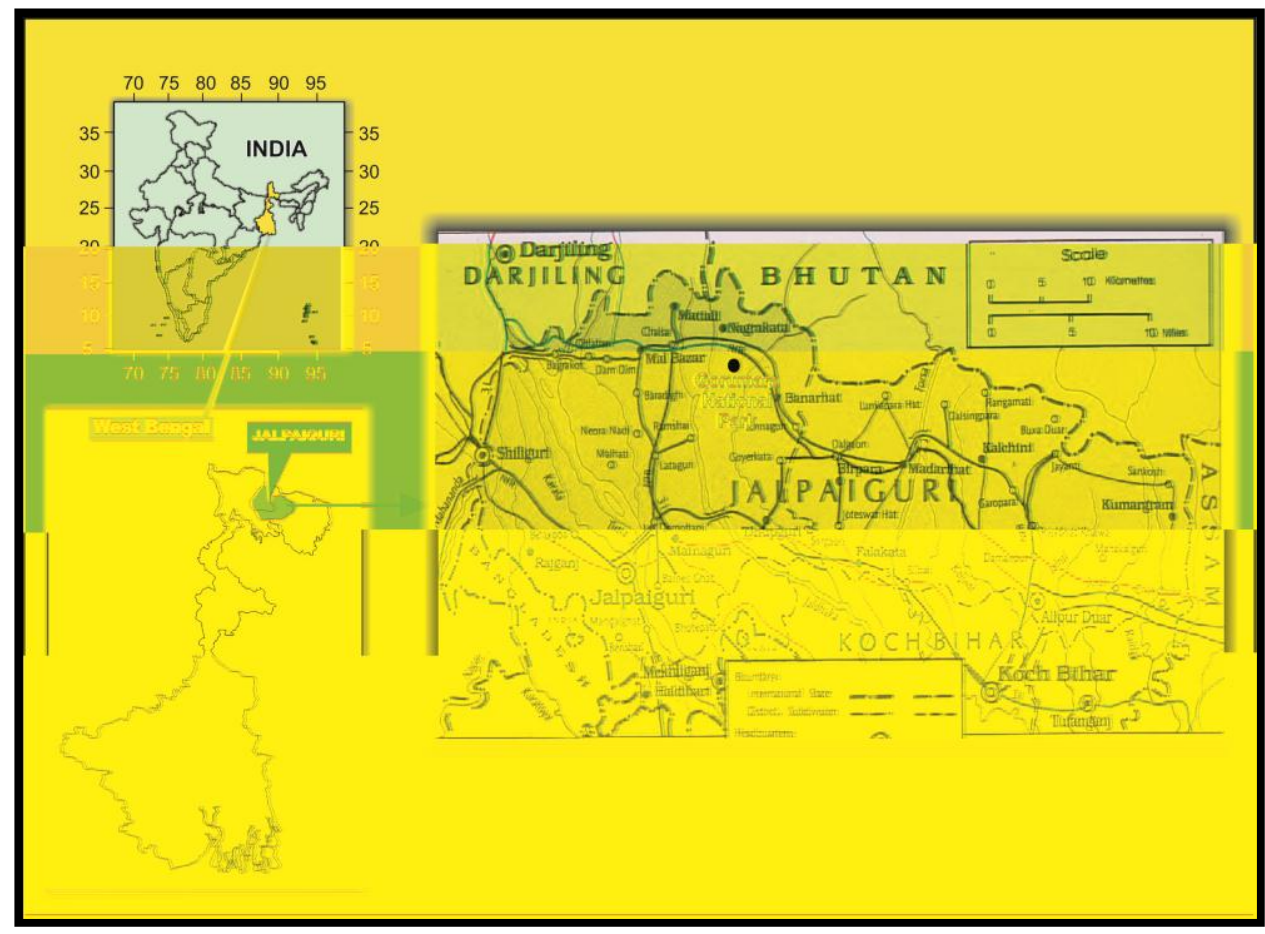

Figure 1: View of the study site

Table 1: General description of the selected species

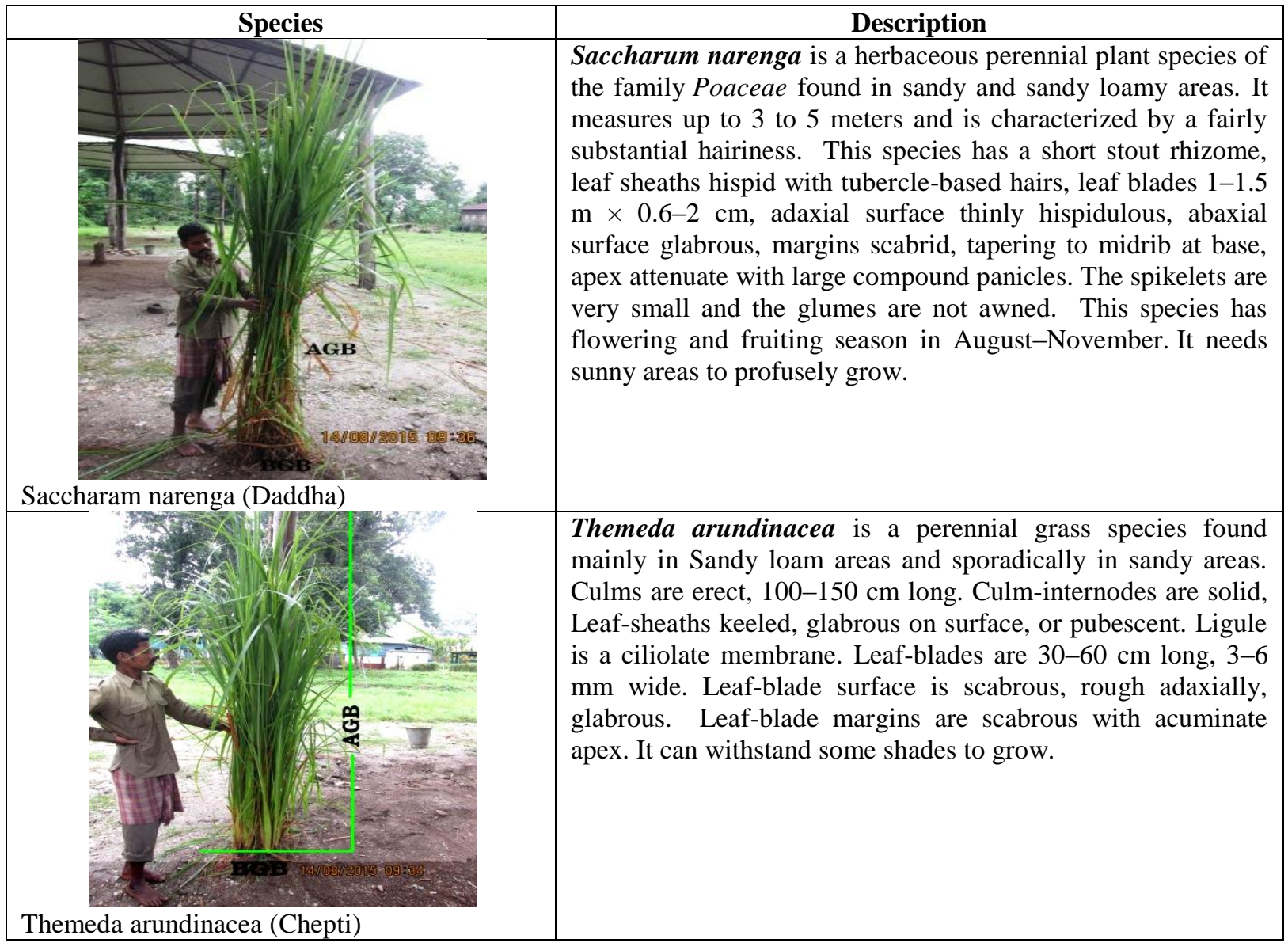




\section{Sampling}

Sampling of biomass of Daddha and Chepti were carried out during August, 2015. Samplings were done considering 10 randomly selected quadrates from each type of habitats (viz. sandy and sandy loam soil) for each type of these grass species. The biomass was estimated by removing all the plants along with roots, rhizomes and shoots from the selected quadrates (each of $1 \mathrm{~m}^{2}$ size); plant materials were thoroughly washed in the ambient water immediately after collection.

This was followed by removal of adhering debris and soil particles on the plant materials. The various vegetative parts (Above and Below Ground) were separated, sundried and weighed and the results were expressed as $\mathrm{Kg} \mathrm{m}^{-2}$ for each species.

\section{Carbon estimation}

Direct estimation of \% carbon in the AGB and BGB was done by Vario MACRO elementar $\mathrm{CHN}$ analyser after grinding and random mixing the over dried above ground and below ground structures separately. This exercise was performed for both the species collected from two different habitats (i.e,. substratum dominated by sandy soil and sandy loam soil).

\section{RESULTS}

The average values of AGB, BGB, AGC and BGC for the two selected species are shown in Figure 2.

\section{Above Ground Biomass}

In the substratum dominated by sandy soil AGB values ranged from $11.23 \mathrm{Kg} \mathrm{m}^{-2}$ (Chepti) to $15.34 \mathrm{Kg} \mathrm{m}^{-2}$ (Daddha). In sandy loam substratum AGB values were $16.72 \mathrm{Kg} \mathrm{m}^{-2}$ and $17.54 \mathrm{Kg} \mathrm{m}^{-2}$ in Daddha and Chepti respectively.

\section{Below Ground Biomass}

The BGB in Chepti sample from sandy soil was $2.22 \mathrm{Kg}$ $\mathrm{m}^{-2}$ while it was $3.46 \mathrm{Kg} \mathrm{m}^{-2}$ in samples collected from sandy loam substratum. In case of Daddha the BGB values were $5.05 \mathrm{Kg} \mathrm{m}^{-2}$ and $6.25 \mathrm{Kg} \mathrm{m}^{-2}$ in samples from sandy and sandy loam soil respectively.

Above Ground Carbon

Above Ground Carbon of Chepti and Daddha were 5.51 $\mathrm{Kg} \mathrm{m}^{-2}$ and $7.18 \mathrm{Kg} \mathrm{m}^{-2}$ in the sandy soil, while values were $8.69 \mathrm{Kg} \mathrm{m}^{-2}$ and $8.04 \mathrm{Kg} \mathrm{m}^{-2}$ in the sandy loam soil.

\section{Below Ground Carbon}

The values were less compared to Above Ground Carbon. The BGC in Chepti and Daddha were $1.04 \mathrm{Kg} \mathrm{m}^{-2}$ and $2.23 \mathrm{Kg} \mathrm{m}^{-2}$ collected from sandy soil while values were $1.69 \mathrm{Kg} \mathrm{m}^{-2}, 2.93 \mathrm{Kg} \mathrm{m}^{-2}$ collected from sandy loam soil.

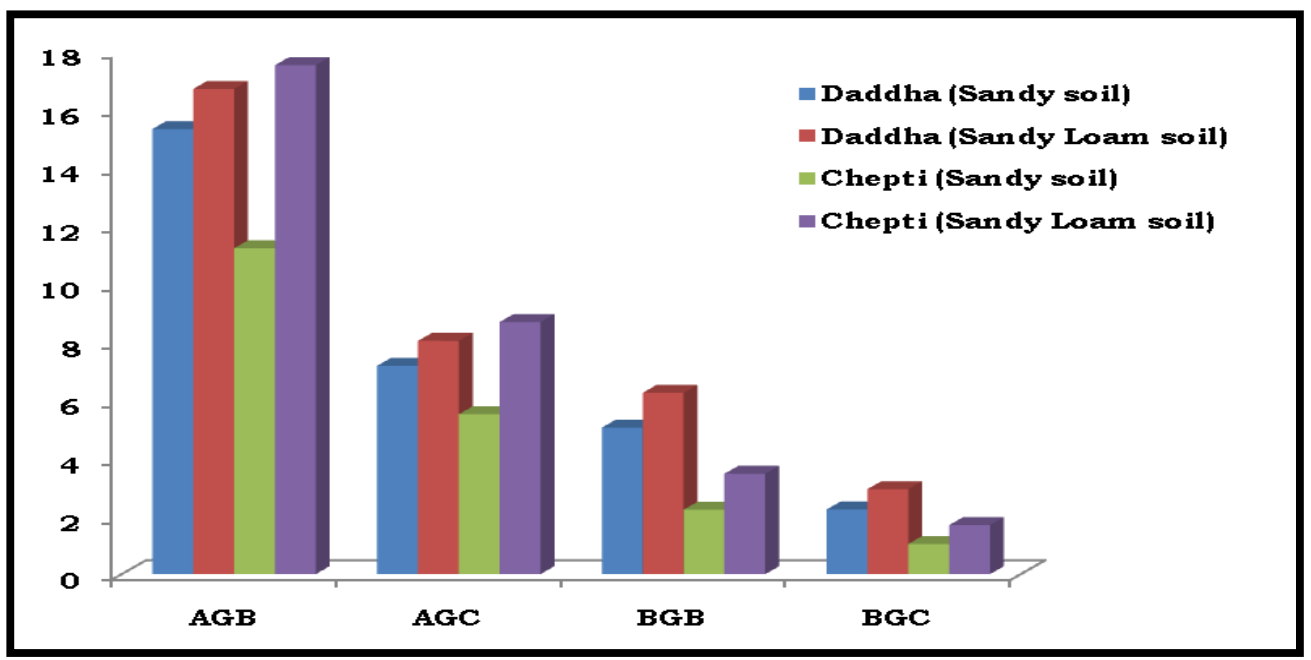

Figure 2: AGB, AGC, BGB and BGC of the selected floral species (in $\mathrm{Kg} \mathrm{m}^{-2}$ ) in GNP

\section{DISCUSSION}

The recent thrust on global warming phenomenon has generated considerable interest in the carbon storing ability of grassland. The carbon sequestration in this unique ecosystem is a function of biomass production capacity which in turn depends upon interaction between edaphic, climatic, topographic factors of an area (Mitra et al., 2011; Mitra and Zaman, 2014; Mitra and Zaman, 2015). Also the habitat and habitats of wild animals alongwith grassland habitat management practices play crucial role in regulating the carbon budget of the ecosystem. Hence results obtained at one place may not be applicable or replicated to another site.

The present study area in the GNP has pronounced habitat diversity with substratum dominated by sandy, sandy loam, loamy soil and marshy area.
The existence of diversified habitats control the rate of decomposition of organic matters generated by wild animals, leaf litter, fallen removed overwood materials and the burnt out plant materials (left over after cut back followed by burning). It is for this reason habitat based potential of storing and sequestering carbon by selected grass species on different land types or substratum characteristics have been worked out.

Our first order analysis indicates relatively higher AGB in the species collected from sandy loam type of substratum compared to those collected from sandy substratum. The carbon sequestered in Chepti collected from sandy substratum is $2.18 \mathrm{~kg} \mathrm{~m}^{-2} \mathrm{year}^{-1}$ while the value is $3.46 \mathrm{~kg}$ $\mathrm{m}^{-2}$ year $^{-1}$ collected from sandy loam type of substratum. In case of Daddha the sequestration rate is $3.14 \mathrm{~kg} \mathrm{~m}^{-2} \mathrm{year}^{-1}$ 
and $3.66 \mathrm{~kg} \mathrm{~m}^{-2} \mathrm{year}^{-1}$ from sandy type of substratum and sandy loam type of substratum respectively. The sequestration rate was assessed considering the age of the species to be around 3 years as informed by the forestors of the GNP.

From the stored carbon data, the $\mathrm{CO}_{2}$ - equivalent for Daddha in sandy and sandy loam type substratum are estimated as 34.53 and 40.26 tonnes respectively. For Chepti, the values are 24.04 tonnes and 38.10 tonnes for sandy and sandy loam type of substratum respectively implying the sandy loam substratum as a better sink of carbon.

The overall discussion thus leads to the conclusion that grass species growing on sandy loam type of substratum are effective sink of carbon. Considering the ecological significance of grassland eco-system in context to wildlife conservation, especially Great Indian one horned Rhinoceros, which is the flagship species of Gorumara National Park, policy must be implemented to preserve and restore the grassland ecosystem which have been destroyed and damaged in many part the globe by activities like habitat fragmentation, habitat destruction, construction of roads, urban development and other industrial activities and some other debatable afforestation activities by removing/ destroying grassland ecosystem with the logic of greater carbon storage in tree species only.

\section{REFERENCES}

1. Mitra, A and Zaman, S. (2014) In: Carbon Sequestration by Coastal Floral Community. Published by The Energy and Resources Institute (TERI) TERI Press, India; Copyright The Energy and Resources Institute; ISBN- 978-81-7993-551-4.

2. Mitra, A. and Zaman, S. (2015) Blue carbon reservoir of the blue planet, published by Springer, ISBN 978-81-322-2106-7 (Springer DOI 10.1007/978-81-322-2107-4).

3. Mitra, A., Sengupta, K. and Banerjee, K. (2011) Standing biomass and carbon storage of above-ground structures in dominant mangrove trees in the Sundarbans. Forest Ecology and Management (ELSEVIER DOI:10.1016/j.foreco.2011.01.012), 261 (7), pp. 1325 $-1335$.

4. Management Plan of Gorumara National Park (2007-08 to 2017-18) published by Divisional Forest Officer, Wild Life Division-II , Jalpaiguri, 2007. 